\title{
ANALISIS KINERJA KEUANGAN PADA PT. HANJAYA MANDALA SAMPOERNA Tbk.
}

\author{
Rona Rosy Nimiangge ${ }^{1}$, Harijanto Sabijono ${ }^{2,}$ Hendrik Gamaliel $^{3}$ \\ ${ }^{1,2,3}$ Akuntansi, Fakultas Ekonomi, Universitas Sam Ratulangi, Manado, 95115, Indoensia \\ E-mail : nimianggeronarosy@yahoo.com
}

\begin{abstract}
Development in technology that happen continuously have made the skills in financial analysis are more needed. Financial statement are the information source for financial position and company financial ferformance analysis. Evaluation of company financial performance in this research using activity ratio and profitability ratio. This research using PT. Hanjaya Mandala Sampoerna Tbk as objek, this decision are based as 1 of 4 big company in cigarettes industry in Indonesia. The summary problem in this research is," How the financial performanceat PT. Hanjaya Mandala Sampoerna Tbk. Based on activity ratio and profitability ratio for year 2015 and 2016?" The activity ratios are calculated with account receivable Turn Over,Inventory Turn Over, Total Asset Turn over,Otherwise Profitability Ratio are calculated with Gross profit Margin, Operating Profit Margin, and Net Profit Margin. The results showed that the ratios of poor activity were seen from the decline in value in the period 2015-2016, while the profitability ratios increased in the period 2015-2016 which indicates the company's ability to generate profits has increased.
\end{abstract}

Keywords : Financial Performance Analysis, Activity, Profitability.

\section{PENDAHULUAN}

Perkembangan teknologi yang terus meningkat dengan pesat menyebabkan semakin diperlukannya keahlian dalam menganalisis laporan keuangan. Untuk itu manajer dituntut memilih informasi dalam jaringan yang luas untuk mengetahui kondisi di masa yang akan datang. Dengan penganalisian laporan keuangan akan membantu pihak-pihak yang berkepentingan dalam memilih dan mengevaluasi informasi dan hanya berfokus dengan informasi tersebut,sehingga setiap perusahaan dituntut untuk dapat meningkatkan daya saingya masing-masing. Namun pada hakikatnya, hampir semua perusahaan perlu penelitian yang sama yaitu bagaimana mengalokasikan sumber daya yang dimiliki secara efektif dan efisien guna mencapai tujuan perusahaan yaitu memperoleh laba maksimal untuk mempertahankan eksistensi perusahaan. Laporan Keuangan merupakan sumber informasi sehubungan dengan posisi keuangan dan kinerja keuangan perusahaan.Data keuangan tersebut dianalisis lebih lanjut sehingga akan diperoleh informasi yang dapat mendukung keputusan yang dibuat. Laporan keuangan ini harus menggambarkan semua data keuangan yang relevan dan telah ditetapkan prosedurnya sehingga laporan keuangan dapat di perbandingkan agar tingkat akurasi analisis dapat di pertanggungjawabkan.

Analisis dan interprestasi keuangan mengkategorikan beberapa teknik dan alat analisis yang dapat di pergunakan untuk menghasilkan informasi yang berguna bagi pihak intern dan ekstern yang terkait dengan perusahaan. Bagi akuntansi, Informasi yang di peroleh itu berfungsi sebagai salah satu bahan pertimbangan dasar dalam proses pengambilan keputusan pengkoordinasian dan pengendalian perusahaan. Pada kenyataanya sering alat-alat analisis tersebut belum di manfaatkan oleh perusahaan. Pengambilan keputusan strategi pada perusahaan sering kali dilakukan oleh pendiri dan keputusan yang diambil bersifat personal, berani serta beresiko tinggi. Dalam jangka pendek pengambilan keputusan dengan cara ini cukup berhasil tetapi untuk jangka panjang dan seiring dengan pertumbuhan perusahaan cara tersebut kurang memadai. 
Ada beberapa cara untuk menilai kondisi kesehatan perusahaan dengan mengunakan analisis kinerja keuangan,namun dalam hal ini penulis hanya menggunakan analisis rasio aktivitas dan akivitas profitabilitas perusahaan, Penulis menganggap hasil dari kedua rasio tersebut penting bagi perusahaan, karena menyangkut kelangsungan hidup perusahaan.Penilaian prestasi perusahaan bagi pihak akuntansi, khususnya untuk mengukur profitabilitas perusahaan merupakan salah satu faktor penting untuk mengetahui tingkat efisiensi perusahaan. Tingginya Profitabilitas perusahaan lebih penting dibanding laba maksimal yang dicapai perusahaan pada setiap periode akuntansi, karena dengan profitabilitas sebagai alat ukur, kita dapat mengetahui sampai sejauh mana kemampuan perusahaan untuk menghasilkan laba yang maksimal dibandingkan dengan modal yang digunakan oleh perusahaan. Untuk itusetiap pemimpin perusahaan dituntut agar mampu mengelola akuntansi perusahaan dengan baik agar dapat mencapai tingkat efisien yang optimal dari penggunaan modalnya.

Objek penelitian ini menggunakan perusahaan PT. Hanjaya Mandala Sampoerna Tbk. PT. Hanjaya Mandala Sampoerna Tbk merupakan 1 dari 4 perusahaan yang terdaftar di Bursa Efek Indonesia dari sektor industry rokok dan merupakan salah satu perusahaan industry rokok yang menyumbang penerimaan bea cukai Negara setiap tahun

\section{TINJAUAN PUSTAKA}

2.1. Konsep Akuntansi

2.1.1. Pengertian akuntansi

A Statement Of Basic Accounting Theory (ASOBAT) (Syakur, 2015:2) mendefinisikan akuntansi sebagai proses mendefinisikan, mengukur, dan menyampaikan informasi ekonomi sebagai bahan informasi dalam hal mempertimbangkan berbagai alternatif dalam pengambilan keputusan. Sedangkan Menurut Mardiasmo (2014: 1), Akuntansi adalah seni pencatatan, penggolongan, peringkasan, dan pelaporan transaksi-transaksi keuangan suatu

\subsubsection{Akuntansi Keuangan}

Kieso, Weygandt dan Warfield (2008:2) Akuntansi Keuangan (Financial Accounting) adalah sebuah proses yang berakhir pada pembuatan laporan keuangan menyangkut perusahaan secara keseluruhan untuk digunakan baik oleh pihak-pihak internal maupun pihak eksternal.

\subsubsection{Pengertian Laporan Keuangan}

Hery (2015:3) laporan keuangan (Financial Statement) merupakan produk akhir dari serangkaian proses pencatatan dan pengikhtisaran data transaksi bisnis.

\subsubsection{Tujuan Laporan Keuangan}

Prastowo (2015:3) Laporan keuangan disusun dengan tujuan untuk menyediakan informasi yang menyangkut posisi keuangan, kinerja dan perubahan posisi keuangan suatu perusahaan yang bermanfaat bagi sejumlah besar pemakai dalam pengambilan keputusan ekonomi.

\subsubsection{Komponen-Komponen Laporan Keuangan}

PSAK 1 mengatur bahwa laporan keuangan lengkap harus mencakup komponenkomponen berikut:

1 Laporan posisi keuangan (neraca) pada akhir periode

2 Laporan laba rugi dan penghasilan komprehensif lain selama periode

3 Laporan perubahan ekuitas selama periode

4 Laporan arus kas selama periode

5 Catatan atas laporan keuangan. 


\subsection{Analisis Kinerja Keuangan}

Pengukuran kinerja keuangan merupakan suatu usaha formal untuk mengevaluasi efisien dan efektivitas perusahaan dalam menghasilkan laba dan posisi kas tertentu. Pengukuran kinerja keuangan adalah penting sebagai sarana dan indicator dalam rangka memperbaiki kegiatan operasional perusahaan. Dengan perbaikan kinerja operasional diharapkan bahwa perusahaan dapat mengalami pertumbuhan keuangan yang lebih baik dan juga dapat bersaing dengan perusahaan lain lewat efisiensi dan efektivitas.

(Hery 2015:29)Pengukuran keuangan dilakukan bersamaan dengan proses analisis. Analisis kinerja keuangan merupakan suatu proses pengkajian kinerja keuangan secara kritis, yang meliputi peninjauan data keuangan, perhitungan, pengukuran, interpretasi dan pemberian solusi terhadap masalah keuangan perusahaan pada suatu periode tertentu. Kinerja keuangan dapat dinilai dengan menggunakan beberapa alat analisis, salah satunya adalah analisis rasio keuangan. (Hery 2015:29).

\subsection{Pengertian dan Jenis - Jenis Rasio Keuangan}

Pengertian rasio keuangan menurut James C Van Horne (Kasmir, 2016:104) merupakan indeks yang menghubungkan dua angka akuntansi dan diperoleh dengan membagi satu angka dengan angka lainnya. Rasio keuangan digunkan untuk mengevaluasi kondisi keuangan dan kinerja perusahaan. Dari hasil rasio keuangan ini akan terlihat kondisi kesehatan perusahaan yang bersangkutan.

Menurut Hery (2015:166) secara garis besar, saat ini dalam praktek setidaknya ada 5 jenis rasio keuangan yang sering digunakan untuk menilai kondisi dan kinerja perusahaan. Kelima jenis rasio keuangan tersebut adalah:

1. Rasio Likuiditas, merupakan rasio yang menggambarkan kemampuan perusahaan dalam memenuhi kewajiban jangka pendeknya yang segera jatuh tempo. Rasio likuiditas diperlukan untuk kepentingan analisis kredit tau analisis risiko keuangan. Rasio likuiditas terdiri atas:

a. Rasio Lancar (Current Ratio), merupakan rasio untuk mengukur kemampuan perusahaan dalam memenuhi kewajiban jangka pendeknya yang segera jatuh tempo dengan menggunakan aset lancar yang tersedia.

b. Rasio Sangat Lancar atau Rasio Cepat (Quick Ratio atau Acid Test Ratio), merupakan rasio yang menunjukkan kemampuan perusahaan dalam memenuhi kewajiban jangka pendeknya yang segera jatuh tempo dengan menggunkan aset sangat lancar (kas+sekuritas jangka pendek-piutang), tanpa memperhitungkan persediaan barang dagang dan aset lancar lainnya.

c. Rasio Kas (Cash Ratio), merupakan rasio yang digunakan untuk mengukur seberapa besar uang kas atau setara kas yang tersedia untuk membayar utang jangka pendek.

2. Rasio Solvabilitas atau Rasio Struktur Modal, merupakan rasio yang menggambarkan kemampuan perusahaan dalam memenuhi seluruh kewajibannya. Rasio solvabilitas terdiri dari:

a. Rasio Utang (Debt Ratio), meruoajan rasio yang digunakan untuk mengukur perbandingan antara total utang dengan total aset. Raio ini juga sering dinamakan sebagai raio utang terhadap aset.

b. Rasio Utang terhadap Ekuitas (Debt to Equity Ratio), merupakan rasio yang digunakan untuk mengukur perbandingan antara total utang dengan total ekuitas. 
c. Rasio Utang Jangka Panjang terhadap Ekuitas (Long Term Debt to Equity Ratio), merupakan rasio yang digunakan untuk mengukur perbandingan antar utang jangka panjang dengan total aset.

d. Rasio Kelipatan Bunga Yang Dihasilkan (Times Interest Earned Ratio), merupakan rasio yang menunjukan kemampuan perusahaan dalam membayar bunga.

e. Rasio Laba Operasional terhadap Kewajiban (Operating Income to Liabilities Ratio), merupakan rasio yang menunjukkan kemampuan perusahaan dalam melunasi seluruh kewajiban. Kemampuan perusahaan disini diukur dari jumlah laba operasional.

3. Rasio Aktivitas, merupakan rasio yang digunakan untuk mengukur tingkat efisiensi atas pemanfaatan sumber daya yang dimiliki perusahaan, atau untuk menilai kemampuan perusahaan dalam menjalankan aktivitasnya sehari-hari. Rasio aktivitas terdiri atas:

a. Perputaran Piutang Usaha (Account Receivable Turn Over), merupakan rasio yang digunakan untuk mengukur beapa lama piutang usaha atau berapa kali dana yang tertanam dalam piutang usaha akan berputar dalam satu periode.

b. Perputaran Persediaan (Inventory Turn Over), merupakan rasio yang digunakan untuk mengukur berapa kali dana yang tertanam dalam persediaan akan berputar dalam satu periode.

c. Perputaran Modal Kerja (Working Capital Turn Over), merupakan raio yang digunakan untuk mengukur keefektifan modal kerja (aset lancar) yang dimiliki perusahaan dalam menghasilkan penjualan.

d. Perputaran Aset Tetap (Fixed Assets Turnover), merupakan rasio yang digunakan untuk mengukur kefektifan aset tetap yang dimiliki perusahaan dalm menghasilkan penjualan.

e. Perputaran Total Aset (Total Assets Turnover), merupakan rasio yang digunakan untuk mengukur berapa

f. jumlah penjualan yang akan dihasilkan dari setiap rupiah dana yang tertanam dalam total aset.

4. Rasio Profitabilitas, merupakan rasio yang menggambarkan kemampuan perusahaan dalam menghasilkan laba. Rasio ini dapat dibedakan menjadi dua jenis yaitu rasio tingkat pengembalian atas investasi dan rasio kinerja operasi.

a. Rasio Tingkat Pengembalian Investasi, rasio yang digunakan untuk menilai kompensasi finansial atas penggunaan aset atau ekuitas terhadap laba bersih. Rasio ini terdiri atas:

(a) Hasil Pengembalian atas Aset (Return On Assets), merupakan rasio yang menunjukkan hasil atas penggunaan aset perusahaan dalam menciptakan laba bersih.

(b) Hasil Pengembalian atas Ekuitas (Return On Equity), merupakan rasio yang menunjukkan hasil atas penggunaan ekuitas perusahaan dalam menciptakan laba bersih.

b. Rasio kinerja operasi adalah rasio yang digunakan untuk mengevaluasi margin laba dari aktivitas operasi. rasio ini terdiri atas:

a. Margin Laba Kotor (Gross Profit Margin), merupakan rasio yang digunakan untuk mengukur besarnya presentase laba kotor atas penjualan bersih. 
b. Margin Laba Operasional (Operating Profit Margin), merupakan rasio yang digunakan untuk mengukur besarnya presentase laba operasional atas penjualan bersih.

c. Margin Laba Bersih (Net Profit Margin), merupakan rasio yang digunakan untuk mengukur besarnya presentase laba bersih atas penjuakan bersih.

5. Rasio penilaian atau rasio ukuran pasar, merupakan rasio yang digunakan untuk mengestimasi nilai intrinsic perusahaan (nilai saham). Rasio ini terdiri atas:

a. Laba Per Lembar Saham Biasa (Earnings Per Share), merupakan rasio untuk mengukur keberhasilan manajemen perusahaan dalam memberikan keuntungan bagi pemegang saham biasa. Rasio ini menunjukkan keterkaitan antara jumlah laba bersih dengan bagian kepemilikan pemegang saham dalam perusahaan investor.

b. Rasio Harga Terhadap Laba (Price Earnings Ratio), merupakan rasio yang menunjukkan hasil perbandingan antara harga pasar per lembar saham dengan laba per lembar saham. Lewat rasio ini, harga saham sebuah emiten dibandingkan dengan laba bersih yang dihasilkan oleh emiten tersebut dalam setahun. Dengan mengetahui besaran PER tersebut, calon investor potensial dapat mengetahui apakah harga sebuah saham tergolong wajar atau tidak sesuai dengan kondisi saat ini dan bukan berdasarkan pada perkiraan di masa mendatang.

c. Imbal Hasil Deviden (Devidend Yield), merupakan rasio yang menunjukkan hasil banding antara deviden tunai per lembar saham dengan harga pasar per lembar saham. Rasio ini digunakan untuk mengukur return atas investasi saham. Lewat rasio ini, investor dapat mengukur besaran deviden yang dibagikan terhadap nilai investasi yang telah ditanamkannya.

d. Rasio Pembayaran Deviden (Dividend Payout Ratio), merupakan rasio yang menunjukkan hasil perbandingan antara deviden tunai per lembar saham dengan laba per lembar saham. Rasio ini menggambarkan jumlah laba dari setiap lembar saham yang dialokasikan dalam bentuk deviden. Sama halnya dengan Devidend Yield, rasio ini juga dapat digunakan sebagai salah satu proksi dalam menetapkan kebijakan deviden, yaitu suatu pengambilan keputusan oleh emiten mengenai besarnya deviden tunai yang akan dibagikan kepada para pemegang saham.

e. Rasio Harga Terhadap Nilai Buku (Price To Book Value Ratio), merupakan rasio yang menunjukkan hasil perbandingan antara harga pasar per lembar saham dengan nilai buku per lembar saham. Rasio ini digunakan untuk mengukur tingkat harga saham apakah overvalued atau undervalued.

\subsection{Penelitian Terdahulu}

Penelitian oleh Masnita Wati (2014) berjudul Analisis Laporan Keuangan Untuk Menilai Kinerja Pada PT. Astra Agro Lestari memiliki Tujuan untuk menilai kinerja PT. Astra Agro Lestari dengan menggunakan metode penelitian Deskriptif. Hasil penelitian Marjin laba kotor perusahaan pada tahun 2011 dan 2012 mengalami kenaikan. Tahun 2013 perusahaan mengalami penurunan. Rasio pendapatan terhadap penjualan perusahaan pada tahun 2011 meningkat, tahun 2012 dan tahun 2013 mengalami penurunan. Rasio pengembalian investasi perusahaan selama tahun 2011 dan 2012 mengalami peningkatan, tahun 2013 perusahaan mengalami penurunan. Laba atas ekuitas perusahaan tahun 2011, 2012 dan 2013 mengalami penurunan. Dengan demikian kinerja pada PT. Astra Agro Lestari 
masih belum efektif. Adapun persamaan dalam penelitian ini yaitu Rasio profitabilitas dalam menilai kinerja sedangkan perbedaanya terdapat pada objek penelitiannya.

Penelitian oleh Hendry Andres Maith (2013) dengan judul Analisis Laporan Keuangan Dalam Mengukur Kinerja Keuangan Pada PT. Hanjaya Mandala Sampoerna Tbk memiliki tujuan untuk mengetahui kinerja keuangan pada PT. Hanjaya Mandala Sampoerna Tbk ditinjau dari analisis rasio keuangan dengan menggunakan merode penelitian Deskriptif. Hasil penelitian Berdasarkan rasio likuiditas setiap tahunnya mengalami peningkatan sehingga keadaan perusahaan dikategorikan dalam keadaan baik (liquid). Dari rasio solvabilitas menunjukkan bahwa modal perusahaan tidak lagi mencukupi untuk menjamin hutang yang diberikan oleh kreditor sehingga keadaan perusahaan dikatakan dalam keadaan tidak baik (insolvable). Ditinjau dengan rasio aktivitas menujukkan peningkatan di setiap tahunnya sehingga keadaan perusahaan dikatakan dalam keadaan baik. Berdasarkan rasio profitabilitas menunjukkan adanya peningkatan dari tahun ke tahun sehingga dapat dikatakan keadaan perusahaan berada pada posisi yang baik. Persamaan dalam penelitian ini yaitu objek penelitian dengankan untuk perbedaannya yaitu tahun penelitian.

\section{METODE PENELITIAN}

\subsection{Jenis Penelitian}

Penelitian ini menggunakan jenis penelitian deskriptif kualitatif. Menurut Kuncoro (2013:12) Penelitian Deskriptif meliputi pengumpulan data untuk diuji hipotesis atau menjawab pertanyaan mengenai status terakhir dari subjek penelitian.

\subsection{Tempat dan Waktu Penelitian}

Penelitian ini mengambil data di Bursa Efek Indonesia Cabang Manado. Dan adapun waktu penelitian selama bulan Juli 2017.

\subsection{Metode pengumpulan Data}

\subsubsection{Jenis Data}

Menurut Kuncoro (2013:145) data adalah sekumpulan informasi yang diperlukan untuk pengambilan keputusan. Menurut jenisnya data di bagi menjadi dua yaitu:

1. Data kualitatif, merupakan data yang tidak dapat diukur dalam skala numerik.

2. Data kuantitatif, merupakan data yang diukur dalam suatu skala numerik atau angka.

Dalam penelitian ini penulis menggunakan data kuantitatif. Data kuantitatif dalam penelitian ini berupa data laporan keuangan PT. Hanjaya Mandala Sampoerna Tbk.

\subsubsection{Sumber Data}

Menurut Sunyoto (2013:21) Sumber data terdiri dari dua yaitu:

a. Data Primer

Data Primer adalah data asli yang dikumpulkan sendiri oleh peneliti untuk menjawab masalah penelitiannya secara khusus.

b. Data Sekunder

Data Sekunder adalah data yang bersumber dari catatan yang ada pada perusahaan dan dari sumber lainnya yaitu dengan mengadakan studi kepustakaan dengan mempelajari buku-buku yang ada hubungannya dengan objek penelitian atau dapat dilakukan dengan menggunakan data dari Biro Pusat Statistik.

Dalam penelitian ini penulis menggunakan data sekunder dimana data yang di dapatkan dari website PT. Hanjaya Mandala Sampoerna Tbk berupa laporan keuangan.

\subsubsection{Teknik Pengumpulan Data}

Teknik pengumpulan data yang digunakan oleh penulis skripsi dalam penelitian ini adalah Dokumentasi, merupakan teknik yang di gunakan dalam pengumpulan data mengenai 
yang diteliti. Dalam penelitian ini dokumen yang dimaksud adalah laporan keuangan PT Hanjaya Mandala Sampoerna Tbk untuk tahun 2015 dan tahun 2016.

\subsection{Metode Analisis}

Untuk memecahkan masalah dalam penelitian ini, maka penulis menggunakan metode deskriptif dengan mengunakan analisis rasio keuangan. Rasio yang dipakai dalam penelitian ini yaitu Rasio Aktivitas dan Rasio Profitabilitas.

1. Rasio Aktivitas

a. Perputaran Piutang Usaha (Account Receivable Turn Over)

$$
\begin{gathered}
\text { Rasio Perputaran Piutang Usaha }=\frac{\text { Penjualan }}{\text { Rata }- \text { rata Piutang Usaha }} \\
\text { Lamanya rata-rata penagihan piutang usaha }=\frac{365 \text { hari }}{\text { Rasio Perputaran Piutang }}
\end{gathered}
$$

b. Perputaran Persediaan (Inventory Turn Over)

$$
\begin{aligned}
\text { Rasio Perputaran Persediaan } & =\frac{\text { Penjualan }}{\text { Rata-rata Persediaan }} \\
\text { Lamanya rata-rata perputaran persediaan } & =\frac{365 \text { hari }}{\text { Rasio Perputaran Persediaan }}
\end{aligned}
$$

c. Perputaran Total Aset (Total Assets Turnover)

$$
\text { Rasio Perputaran Total Aset }=\frac{\text { Penjualan }}{\text { Rata-rata Total Aset }}
$$

2. Rasio Profitabilitas

a. Margin Laba Kotor (Gross Profit Margin)

$$
\text { Margin Laba Kotor }=\frac{\text { Laba Kotor }}{\text { Penjualan Bersih }}
$$

b. Margin Laba Operasional (Operating Profit Margin)

$$
\text { Margin Laba Operasional }=\frac{\text { Laba Operasional }}{\text { Penjualan Bersih }}
$$

c. Margin Laba Bersih (Net Profit Margin)

$$
\text { Margin Laba Bersih }=\frac{\text { Laba Bersih }}{\text { Penjualan Bersih }}
$$




\section{HASIL ANALISIS DAN PEMBAHASAN \\ 4.1. Hasil analisis Perhitungan Rasio Aktivitas \\ 1. Rasio Perputaran Piutang}

Tabel 1.1 Rasio Perputaran Piutang (Dinyatakan dalam jutaan Rupiah)

\begin{tabular}{lllll}
\hline Tahun & Penjualan Bersih & $\begin{array}{l}\text { Rata-Rata } \\
\text { Piutang }\end{array}$ & Kali & $\begin{array}{l}\text { Lamanya Rata- } \\
\text { Rata Penagihan }\end{array}$ \\
\hline $\mathbf{2 0 1 5}$ & Rp. $89,069,306$ & Rp. 2,912,382 & 30 & 12 \\
\hline $\mathbf{2 0 1 6}$ & Rp. $95,466,657$ & Rp. 4,861,623.50 & 19 & 19 \\
\hline
\end{tabular}

Sumber : Data Olahan (2017)

2. Rasio Perputaran Persediaan

Tabel 1.2 Rasio Perputaran Persediaan (Dinyatakan dalam jutaan Rupiah)

\begin{tabular}{lllll}
\hline Tahun & $\begin{array}{l}\text { Harga Pokok } \\
\text { Penjualan }\end{array}$ & $\begin{array}{l}\text { Rata-Rata } \\
\text { Persediaan }\end{array}$ & Kali & $\begin{array}{l}\text { Lamanya Rata- } \\
\text { Rata } \\
\text { Persediaan }\end{array}$ \\
\hline $\mathbf{2 0 1 5}$ & Rp. $67,304,917$ & Rp. $18,251,554.50$ & 3.6 & 101 \\
\hline $\mathbf{2 0 1 6}$ & Rp. $71,611,981$ & Rp. $19,256,773$ & 3.7 & 98 \\
\hline
\end{tabular}

Sumber : Data Olahan (2017)

3. Rasio Perputaran Total Aset

Tabel 1.3 Rasio Perputaran Total Aset (Dinyatakan dalam jutaan Rupiah)

\begin{tabular}{|c|c|c|c|}
\hline Tahun & Penjualan & $\begin{array}{l}\text { Rata-rata Total } \\
\text { Aset }\end{array}$ & Kali \\
\hline 2015 & Rp. $89,069,306$ & Rp. 33,195,677 & 2.6 \\
\hline 2016 & Rp. $95,466,657$ & Rp. $40,259,500.5$ & 2.3 \\
\hline
\end{tabular}

Sumber : Data Olahan (2017)

Perhitungan Rasio Aktivitas

1. Margin Laba Kotor (Gross Profit Margin)

Tabel 1.4 Rasio Gross Profit Margin

(Dinyatakan dalam jutaan Rupiah)

\begin{tabular}{llll}
\hline Tahun & Laba Kotor & Penjualan Bersih & \% \\
\hline $\mathbf{2 0 1 5}$ & Rp. $21,764,389$ & Rp. 89,069,306 & 24.4 \\
\hline $\mathbf{2 0 1 6}$ & Rp. 23,854,676 & Rp. 95,466,657 & 24.9 \\
\hline
\end{tabular}

Sumber : Data Olahan (2017) 
2. Margin Laba Bersih (Net Profit Margin),

Tabel 1.5 Rasio Net Profit Margin

(Dinyatakan dalam jutaan Rupiah)

\begin{tabular}{llll}
\hline Tahun & $\begin{array}{l}\text { Laba } \\
\text { Setelah Pajak }\end{array}$ & $\begin{array}{l}\text { Bersih } \\
\text { Penjualan Bersih }\end{array}$ & \% \\
\hline $\mathbf{2 0 1 5}$ & Rp. $10,363,308$ & Rp. 89,069,306 & 11 \\
\hline $\mathbf{2 0 1 6}$ & Rp. $12,762,229$ & Rp. 95,466,657 & 13 \\
\hline
\end{tabular}

Sumber : Data Olahan (2017)

3. Margin Laba Operasional (Operating Profit Margin)

Tabel 1.6 Rasio Margin Laba Operasional (Dinyatakan dalam jutaan Rupiah)

\begin{tabular}{llll}
\hline Tahun & Laba Operasional & Penjualan & \% \\
\hline $\mathbf{2 0 1 5}$ & Rp. 13,932,644 & Rp. 89,069,306 & 15 \\
\hline $\mathbf{2 0 1 6}$ & Rp. $17,011,447$ & Rp. $95,466,657$ & 17 \\
\hline
\end{tabular}

Sumber : Data Olahan (2017)

Perbandingan Rasio Aktivitas Dan Profitabilitas Tahun 2015 Dan 2016

Tabel 1.7 Perbandingan Rasio Aktivitas Dan Profitabilitas Tahun 2015 Dan 2016

\begin{tabular}{llll}
\hline Rasio & $\mathbf{2 0 1 5}$ & $\mathbf{2 0 1 6}$ & Keterangan \\
\hline Rasio Aktivitas & & & \\
\hline Rasio Perputaran Piutang & 30 & 19 & Kurang Baik \\
\hline Rasio Perputaran Persediaan & 3.6 & 3.7 & Baik \\
\hline Rasio Perputaran Total Aset & 2.6 & 2.3 & Kurang baik \\
\hline Rasio Profitabilitas & & & \\
\hline Margin Laba Kotor & 24.4 & 24.9 & Baik \\
\hline Margin Laba Bersih & 11 & 13 & Baik \\
\hline Margin Laba Operasional & 15 & 17 & Baik \\
\hline
\end{tabular}

Sumber : Data Olahan (2017)

\subsection{Pembahasan}

\section{Rasio Aktivitas}

Dari hasil penelitian dapat dilihat bahwa nilai rasio perusahaan dari tahun 2015 ke tahun 2016 mengalami penurunan sehingga dapat dikatakan kurang baik, perusahaan harus lebih meningkatkan kinerja khususnya untuk perputaran piutang dan perputaran total aset.

\section{Rasio Profitabilitas}

Dari hasil penelitian secara keseluruhan, untuk rasio profitabilitas ini perusahaan berada dalam keadaan yang baik. Hal ini dapat kita lihat pada peningkatan yang ada dalam data rasio profitabilitas. Peningkatan ini menunjukkan bahwa keberhasilan perusahaan untuk menghasilkan laba setiap tahun semakin meningkat. 


\section{KESIMPULAN DAN SARAN}

\subsection{Kesimpulan}

Dari hasil penelitian dan pembahasan dapat di tarik kesimpulan bahwa:

1. Rasio Aktivitas perusahaan dapat di katakana kurang baik dimana dari 3 rasio yang digunakan ada 2 rasio yang kurang baik dimana nilai rasio perputaran total aset dan perputaran piutang mengalami penurunan, untuk rasio perputaran persediaan mengalami peningkatan dari tahun 2015 ke tahun 2016. Sehingga perusahaan harus lebih meningkatkan kinerja di bidang aktivitas.

2. Rasio Profitabilitas perusahaan dalam posisi baik. Hal ini dapat dilihat dari ke 3 rasio yang dipakai yaitu rasio margin laba kotor, margin laba bersih dan margin laba operasional mengalami peningkatan dari tahun 2015 ke tahun 2016. Hal ini dapat menunjukan keberhasilan perusahaan dalam menghasilkan laba setiap tahun semakin meningkat.

3. Secara keseluruhan dapat dikatakan bahwa kinerja keuangan PT. Hanjaya Mandala Sampoerna Tbk dalam keadaan cukup baik dari segi Rasio Aktivitas dan Rasio Profitabilitas

\subsection{Saran}

Berdasarkan kesimpulan yang diperoleh dari analisis data, maka penulis skripsi memberikan saran sebagai berikut:

1. Bagi Perusahaan

Diharapkan bagi perusahaan bahwa dari segi rasio aktivitas untuk rasio perputaran persediaan agar supaya di pertahankan sedangkan untuk rasio perputaran piutang dan rasio perputaran total aset lebih di perbaiki agar kontribusi aset terhadap penjualan lebih baik. Dari segi rasio Profitabilitas harus tetap di pertahankan dalam keberhasilan perusahaan menghasilkan laba.

2. Bagi penelitian selanjutnya

Diharapkan dapat bermanfaat serta menjadi referensi bagi rekan-rekan yang ingin meneliti lebih lanjut tentang analisis kinerja keuangan.

\section{DAFTAR PUSTAKA}

Donald E. Kieso, Jerry J, Weygandt and Teery D. Warfield. 2008. Akuntansi Intermediate. Edisi 12. Jakarta. Erlangga

Hendry Andres Maith. 2013. Analisis Laporan Keuangan Dalam Mengukur Kinerja Keuangan Pada PT. Hanjaya Mandala Sampoerna Tbk. Jurnal EMBA. Vol.1 No.3 September 2013.

Hery. 2015. Analisis laporan keuangan pendekatan rasio keuangan. Center for Academic Publishing Service (CAPS). Yogyakarta.

IAI. 2013. Exposure Draft Pernyataan Standar Akuntansi Keuangan No. 1 (Revisi 2013). diakses 10 januari 2016.

Kasmir. 2016. Analisis Laporan Keuangan. PT Raja Grafindo Persada. Jakarta.

Kuncoro, Mudrajad. 2013. Metode Riset Untuk Bisnis \& Ekonomi. Erlangga. Jakarta.

Mardiasmo. 2014. Akuntansi Keuangan Dasar 1. Cetakan ke Empat. BPFE, yogyakarta.

Prastowo, Dwi. 2015. Analisis Laporan Keuangan konsep dan aplikasi. Unit Penerbit Dan Percetakan STIM YKPN. Yogyakarta.

Sunyoto, Danang. 2013. Metodologi Penelitian Akuntansi. PT Refika Aditan. Bandung.

Syakur S, Ahmad. 2015. Intermediate Accounting. Pembuka Cakrawala. Jakarta.

Wati Masnita. 2014. Analisis Laporan Keuangan Untuk Menilai Kinerja Pada PT. Astra Agro Lestari Tbk. Universitas Pasir Pengaraian. 